\title{
Cocaine-Conditioned Place Preference by Dopamine- Deficient Mice Is Mediated by Serotonin
}

\author{
Thomas S. Hnasko, ${ }^{1 *}$ Bethany N. Sotak, ${ }^{2 *}$ and Richard D. Palmiter ${ }^{2}$ \\ ${ }^{1}$ Graduate Program in Neurobiology and Behavior and ${ }^{2}$ Howard Hughes Medical Institute and Department of Biochemistry, University of Washington, \\ Seattle, Washington 98195
}

\begin{abstract}
Rodents learn to associate the rewarding effects of drugs with the environment in which they are encountered and, subsequently, will display a conditioned place preference (CPP) for that environment. Cocaine-induced CPP is generally thought to be mediated through inhibition of the dopamine transporter and the consequent increase in extracellular dopamine. However, here we report that dopaminedeficient (DD) mice formed a CPP for cocaine that was not blocked by a dopamine $\mathrm{D}_{1}$-receptor antagonist. Fluoxetine, a serotonin transporter (SERT) inhibitor, produced CPP in DD, but not control mice, suggesting that serotonin mediates cocaine CPP in DD mice. Inhibition of dopamine neuron firing by pretreatment with quinpirole, a dopamine $\mathrm{D}_{2}$-receptor agonist, blocked both cocaine- and fluoxetine-induced CPP in DD mice. These findings are consistent with the hypothesis that, in the absence of dopamine, cocaine-mediated SERT blockade activates dopamine neurons, which then release some other neurotransmitter that contributes to cocaine reward in DD mice.
\end{abstract}

Key words: cocaine; conditioned place preference; dopamine; dopamine-deficient; dopamine transporter; serotonin transporter

\section{Introduction}

Cocaine produces its effects on the CNS through blockade of the plasma membrane monoamine-reuptake transporters and the consequent increase in monoamine signaling. Although cocaine blocks the dopamine (DAT), serotonin (SERT), and norepinephrine (NET) transporters with comparable efficacy (Rothman and Baumann, 2003), most of the psychoactive effects of cocaine have been attributed to DAT blockade. For instance, the reinforcing properties of monoamine-transporter blockers strongly correlate with their ability to bind to DAT (Ritz et al., 1987). Treatment with dopamine-receptor antagonists or dopamine-specific lesions can inhibit the acquisition or expression of cocaineinduced conditioned place preference (CPP) and alter cocaine self-administration responses (Pettit et al., 1984; Cervo and Samanin, 1995; Pruitt et al., 1995) (for review, see Pierce and $\mathrm{Ku}-$ maresan, 2006). However, other studies have failed to show clear effects of dopamine-receptor antagonists or dopamine-neuron lesions on reward-related cocaine responses (Spyraki et al., 1982). Moreover, some specific DAT blockers produce little or no reinforcing effects despite causing large increases in dopamine signaling (Rothman and Glowa, 1995).

Received July 10, 2007; revised Sept. 11, 2007; accepted 0ct. 2, 2007.

T.S.H. was supported in part by National Institute of General Medical Sciences Grant PHS NRSA T32 GM07270. This work was supported in part by National Institutes of Health Grant P50-DA13410. We thank Nora Meneses for help maintaining the DD mouse colony and Charles Chavkin and Larry Zweifel for their input during the preparation of this manuscript.

*T.S.H. and B.N.S. contributed equally to this work.

Correspondence should be addressed to Richard D. Palmiter, Howard Hughes Medical Institute, Box 357370 ,

University of Washington, Seattle, WA 98195. E-mail: palmiter@u.washington.edu.

T. S. Hnasko's present address: University of California, San Francisco, CA 94158.

DOI:10.1523/JNEUROSCI.3133-07.2007

Copyright $\odot 2007$ Society for Neuroscience $\quad$ 0270-6474/07/2712484-05\$15.00/0
Nondopaminergic manipulations can also modify the reinforcing properties of cocaine. In particular, serotonin signaling clearly modulates cocaine responses. For example, 5- $\mathrm{HT}_{1 \mathrm{~b}}$ receptor knock-out $(\mathrm{KO})$ mice display enhanced cocaine selfadministration (Rocha et al., 1998b), and 5- $\mathrm{HT}_{1 \mathrm{~b}}$ agonist treatment (Parsons et al., 1998) or viral-mediated 5- $\mathrm{HT}_{1 \mathrm{~b}}$ expression in nucleus accumbens (NAc) sensitizes animals to cocaine reward (Neumaier et al., 2002).

Studies using monoamine-transporter knock-out mice suggest an overlapping role for monoamine signaling in mediating cocaine CPP. DAT-KO mice continue to self-administer cocaine and display cocaine CPP (Rocha et al., 1998a; Sora et al., 1998). Although SERT-KO and NET-KO mice also readily develop cocaine CPP (Sora et al., 1998; Xu et al., 2000), DAT/SERT double-KO mice do not (Sora et al., 2001), suggesting that cocaine-mediated DAT or SERT blockade is sufficient for CPP but that alone, neither is necessary for cocaine reward. Unexpectedly, extracellular dopamine levels still increase in the NAc after cocaine administration to DAT-KO mice (Carboni et al., 2001; Mateo et al., 2004); the authors suggest that although DAT is not a necessary substrate for cocaine-induced reward, dopamine signaling may still be an essential mediator.

Here we address the question of whether dopamine is essential for cocaine-induced CPP by taking advantage of a dopaminedeficient (DD) mouse model in which tyrosine hydroxylase, the rate-limiting enzyme for catecholamine biosynthesis, is inactivated in dopamine neurons but not other catecholaminergic neurons (Zhou and Palmiter, 1995). We have previously shown that DD mice are capable of learning and expressing a CPP for morphine in the dopamine-depleted state (Hnasko et al., 2005). Those experiments demonstrated that the acute increase in dopamine signaling normally produced by morphine is not re- 
quired for the hedonic impact ("liking") of morphine, nor for mice to form a conditioned association ("learning") (Berridge, 2007). In this study, we show that DD mice are also able to express a CPP for cocaine independently of dopamine release. Furthermore, we show that in the absence of dopamine, cocaine CPP is mediated by SERT blockade, but we suggest that this cocaine CPP may still be dependent on dopamine neuron activity.

\section{Materials and Methods}

Subjects and treatments. Dopamine-deficient $\left(T h^{-1-} ; D b h^{T h /+}\right)$ mice carrying two inactive Tyrosine hydroxylase (Th) alleles, one intact Dopamine $\beta$-hydroxylase allele $\left(D b h^{+}\right)$, and one $D b h$ allele with a targeted insertion of the Th gene $\left(D b h^{T h}\right)$ were created as described previously (Zhou and Palmiter, 1995). Beginning at approximately postnatal day 10, DD mice received daily injections of L-dopa to induce feeding. Controls included animals that carry at least one intact $T h$ allele and one intact $D b h$ allele. Mice were backcrossed several generations and are $>90 \% \mathrm{C} 57 \mathrm{BL} / 6$ $(<10 \% 129 / \mathrm{SvEv})$. Attempts to backcross further were thwarted by declining birth rates and increased DD mortality. All mice were housed under a $12 \mathrm{~h}$ light/dark cycle and temperature-controlled environment with food (5LJ5; Purina, St. Louis, MO) and water available ad libitum. All drugs were obtained from Sigma (St Louis, MO), dissolved in vehicle $(0.9 \%$ saline $)$, and administered at a volume of $10 \mu \mathrm{l} / \mathrm{g}$ (except L-dopa). Treatments included L-dopa (i.p.), caffeine (i.p.), saline (s.c.), cocaine (s.c.), amphetamine (i.p.), SCH-23390 (i.p.), fluoxetine (s.c.), methiothepin (i.p.), and quinpirole (i.p.). L-Dopa (1.5 mg/ml) and ascorbic acid $(2.5 \mathrm{mg} / \mathrm{ml})$ were dissolved in PBS (33 $\mu \mathrm{l} / \mathrm{g}$ to deliver L-dopa at $50 \mathrm{mg} /$ $\mathrm{kg}$ ). All mice were treated in accordance with guidelines established by the National Institutes of Health and the University of Washington Animal Care Committee.

Conditioned place preference. All CPP experiments were conducted using Plexiglas three-chamber boxes with two equal-sized compartments $(20 \times 20 \mathrm{~cm})$ separated by a neutral gray chamber $(20 \times 7.5 \mathrm{~cm})$. The boxes were separated by two sliding doors. The two large compartments had different-colored walls (black or white) and different flooring (hard punched metal or stiff wire mesh) and were cued with different scents beneath the flooring (clove or ginger). The boxes were balanced such that mice averaged equal amounts of time spent in both large chambers during pretest sessions. Each animal was assigned one compartment for saline pairing and the other compartment for cocaine pairing. The groups were balanced such that each group averaged equal amounts of time in each of the assigned conditioning compartments (i.e., an unbiased paradigm). CPP experiments were performed essentially as described previously (Hnasko et al., 2005). Briefly, on the pretest day $(16-23 \mathrm{~h}$ after $\mathrm{L}$-dopa), mice were pretreated with caffeine $(15 \mathrm{mg} / \mathrm{kg})$ to enable locomotion $5 \mathrm{~min}$ before being placed in the center chamber and allowed to explore the entire apparatus for $25 \mathrm{~min}$. These sessions were recorded using a digital video camera (Sony, Tokyo, Japan). Videos were analyzed using Ethovision software (Noldus, Wageningen, The Netherlands) to determine the time spent in each compartment. Any animal that spent $>65 \%$ of their time in either large compartment or $>40 \%$ of their time in the neutral middle compartment were discarded from the study before assigning sides, because of the confounding factor of an endogenous preference or aversion. On pairing days, each day each animal was treated with saline and confined to one side for $25 \mathrm{~min}$ in the morning and treated with drug and confined to the opposite side for 25 $\min$ in the afternoon. Conditioning drugs included cocaine, fluoxetine, $\mathrm{SCH}-23390$, methiothepin, and quinpirole, and there was a delay of 0,0 , 10,30 , or $15 \mathrm{~min}$, respectively, after drug treatment before placement in the conditioning chambers. Morning and afternoon conditioning sessions began $16-18 \mathrm{~h}$ or $19-21 \mathrm{~h}$ after the previous day's L-dopa treatment, respectively, and mice received L-dopa no sooner than $1 \mathrm{~h}$ after the afternoon conditioning treatment. Thus, all pairing sessions were conducted in the dopamine-depleted state and in the absence of caffeine. After $3 \mathrm{~d}$ of conditioning, a posttest session was conducted identically to the pretest. Data represent the percentage of time spent in the drugpaired, compared with the saline-paired, compartment before and after conditioning (i.e., the ratio does not include time spent in the unpaired center chamber).

The experiments with SCH-23390, quinpirole, methiothepin, and amphetamine pretreatments required extending conditioning sessions over $6 \mathrm{~d}$, alternating one saline (days 2, 4, and 6) or drug (days 3, 5, and 7) session per day. SCH-23390 (10 $\mu \mathrm{g} / \mathrm{kg})$, methiothepin $(30 \mu \mathrm{g} / \mathrm{kg})$, or quinpirole $(50 \mu \mathrm{g} / \mathrm{kg})$ were administered $\sim 18 \mathrm{~h}$ after L-dopa and 10, 30, and $15 \mathrm{~min}$, respectively, before conditioning treatments (i.e., saline, cocaine, or fluoxetine). Mice received L-dopa no sooner than $3 \mathrm{~h}$ after conditioning treatments. For the experiments with amphetamine, mice were treated with amphetamine $(3 \mathrm{mg} / \mathrm{kg})$ in their home cages and $3 \mathrm{~h}$ later mice received saline or cocaine $(10 \mathrm{mg} / \mathrm{kg})$ in conditioning chambers. Baseline and testing sessions were performed as described above except that testing was performed on day 8 .

\section{Results}

\section{Cocaine elicits CPP by DD mice}

DD mice are severely hypoactive and do not readily explore a conditioning chamber. However, caffeine stimulates locomotion by $\mathrm{DD}$ mice, and caffeine treatment is sufficient to induce the locomotor activity required to explore a CPP box (Hnasko et al., 2005). Thus, DD and littermate-control mice were treated with caffeine during baseline and testing sessions of our CPP paradigm, but saline- and cocaine-pairing sessions were performed in the absence of caffeine. Under these conditions, control mice formed a significant CPP for cocaine at doses ranging from 5 to $15 \mathrm{mg} / \mathrm{kg}$ (Fig. 1A). DD mice also developed a CPP for cocaine, but only at doses of 7.5 and $10 \mathrm{mg} / \mathrm{kg}$ (Fig. 1A). DD mice received cocaine $19-23 \mathrm{~h}$ after previous L-dopa injections, at which time brain dopamine levels are $<1 \%$ of control levels (Szczypka et al., 1999). However, because dopamine receptors in DD mice are hypersensitive (Kim et al., 2000), this residual dopamine has the potential to be behaviorally relevant. We have previously presented evidence that amphetamine treatment depletes this residual dopamine (Heusner et al., 2003). Therefore, to ensure that residual dopamine was not responsible for mediating cocaine $\mathrm{CPP}$ in DD mice, we treated mice with amphetamine $3 \mathrm{~h}$ before each pairing session. Amphetamine pretreatment did not disrupt preference for $10 \mathrm{mg} / \mathrm{kg}$ cocaine in either control or DD mice (Fig. $1 B$ ), demonstrating that residual dopamine is not necessary for cocaine CPP in DD mice. Furthermore, pretreatment with SCH-23390 $(10 \mu \mathrm{g} / \mathrm{kg})$, a $\mathrm{D}_{1}$-receptor antagonist, did not block cocaine CPP in DD mice, although it blocked preference in control mice (Fig. 1C), as has been previously reported (Cervo and Samanin, 1995; Pruitt et al., 1995). This dose of SCH-23390 did not independently induce preference or aversion in DD mice (percentage time on SCH-23390-paired chamber during pretest $=49.6 \pm 4.7 \%$; posttest $=54.7 \pm 10.0 \% ; n=6$ ). These results indicate that moderate doses of cocaine can elicit CPP in the absence of dopamine signaling in DD mice.

\section{Serotonin mediates CPP by DD mice}

To determine whether the rewarding effects of cocaine in DD mice could be caused by increased serotonin signaling resulting from cocaine-mediated SERT blockade, we tested the effects of fluoxetine, a selective serotonin reuptake inhibitor, in our CPP paradigm. A dose-response experiment performed using control mice revealed that fluoxetine produced significant conditioned place aversion (CPA) at 15 or $10 \mathrm{mg} / \mathrm{kg}$, but not at $5 \mathrm{mg} / \mathrm{kg}$ (Fig. $2 A)$. We therefore tested DD mice with fluoxetine at $5 \mathrm{mg} / \mathrm{kg}$ and observed robust CPP (Fig. $2 B$ ). These results suggest that in the absence of dopamine, SERT blockade mediates reward, and provides a plausible mechanism for cocaine-mediated CPP in DD mice. 


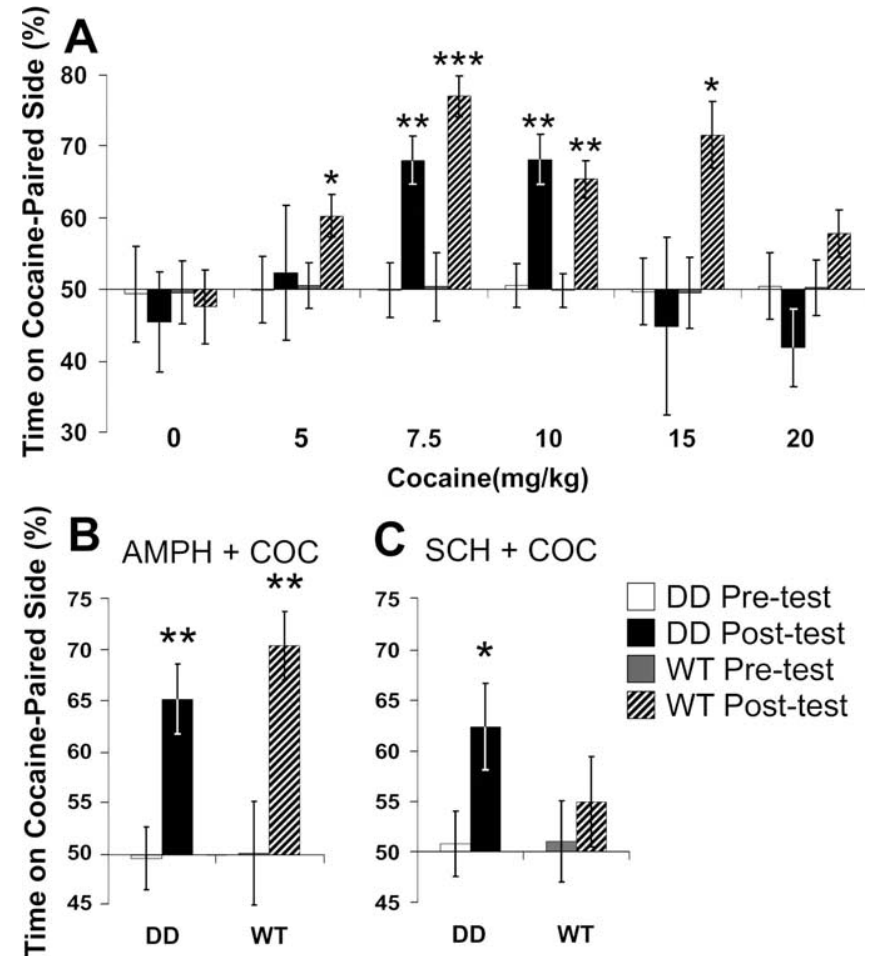

Figure 1. Cocaine CPP without dopamine. A, Dose-response for cocaine CPP by DD and control mice. All phases of this experiment were conducted in the absence of L-dopa, and caffeine was used to induce locomotion during testing but not conditioning phases of the experiment. DD mice show significant preferences for a narrower range of cocaine doses compared with controls. The numbers of control and DD mice, respectively, for each dose of cocaine are shown in parentheses: $0 \mathrm{mg} / \mathrm{kg}(7,7) ; 5 \mathrm{mg} / \mathrm{kg}(8,8) ; 7.5 \mathrm{mg} / \mathrm{kg}(10,10) ; 10 \mathrm{mg} / \mathrm{kg}(25,25)$; $15 \mathrm{mg} / \mathrm{kg}(8,6)$ and $20 \mathrm{mg} / \mathrm{kg}(13,16)$. B, Amphetamine (AMPH; $3 \mathrm{mg} / \mathrm{kg})$ pretreatment, to purge residual dopamine from $D D$ mice, did not disrupt preference for the chamber paired to cocaine (COC; $10 \mathrm{mg} / \mathrm{kg}) ;(D D, n=12$; controls, $n=10)$. C, Pretreatment with SCH-23390 $(\mathrm{SCH} ; 10 \mu \mathrm{g} / \mathrm{kg})$ did not block cocaine ( $10 \mathrm{mg} / \mathrm{kg})$ CPP in DD mice, but blocked CPP by controls $(\mathrm{DD}, n=8 ;$ controls,$n=9)$. All data are presented as means \pm SEM of the percentage of time spent in the drug-paired during the pretesting and posttesting sessions; two-tailed paired $t$ test comparing time spent on drug-paired side before and after conditioning within genotypes and doses, ${ }^{*} p<0.05 ;{ }^{* *} p<0.01 ;{ }^{* * *} p<0.001$. WT, Wild type.

In addition, pretreatment with the $5-\mathrm{HT}_{1}$ receptor antagonist methiothepin $(30 \mu \mathrm{g} / \mathrm{kg}$ ) blocked the formation of CPP for cocaine (Fig. 2D) and fluoxetine (Fig. 2E). This dose of methiothepin did not independently induce a significant preference or aversion in DD mice (Fig. 2C), although a trend toward aversion was observed, which became significant at higher doses in control mice (data not shown).

Dopamine $\mathrm{D}_{2}$-receptor activation abolishes cocaine and fluoxetine CPP by DD mice

Because multiple lines of evidence suggest that dopamine neurons are critical for reward learning in general and for cocaine reward in particular (Schultz, 2002; Wise, 2004; Pierce and Kumaresan, 2006), and because dopamine neurons release transmitters other than dopamine, we sought to explore the hypothesis that dopamine neurons are necessary for CPP even in the absence of dopamine release. To do this, we tested the effects of quinpirole $(50 \mu \mathrm{g} / \mathrm{kg})$, a dose that inhibits dopamine neuron activity in DD mice (Robinson et al., 2004). First, we demonstrated that quinpirole alone (at $50 \mu \mathrm{g} / \mathrm{kg}$ ) produces no substantial preference or aversion (Fig. $3 A$ ). However, when control or $\mathrm{DD}$ mice were treated with quinpirole before pairing, cocaine CPP was abolished (Fig. 3B). Indeed, quinpirole pretreatment

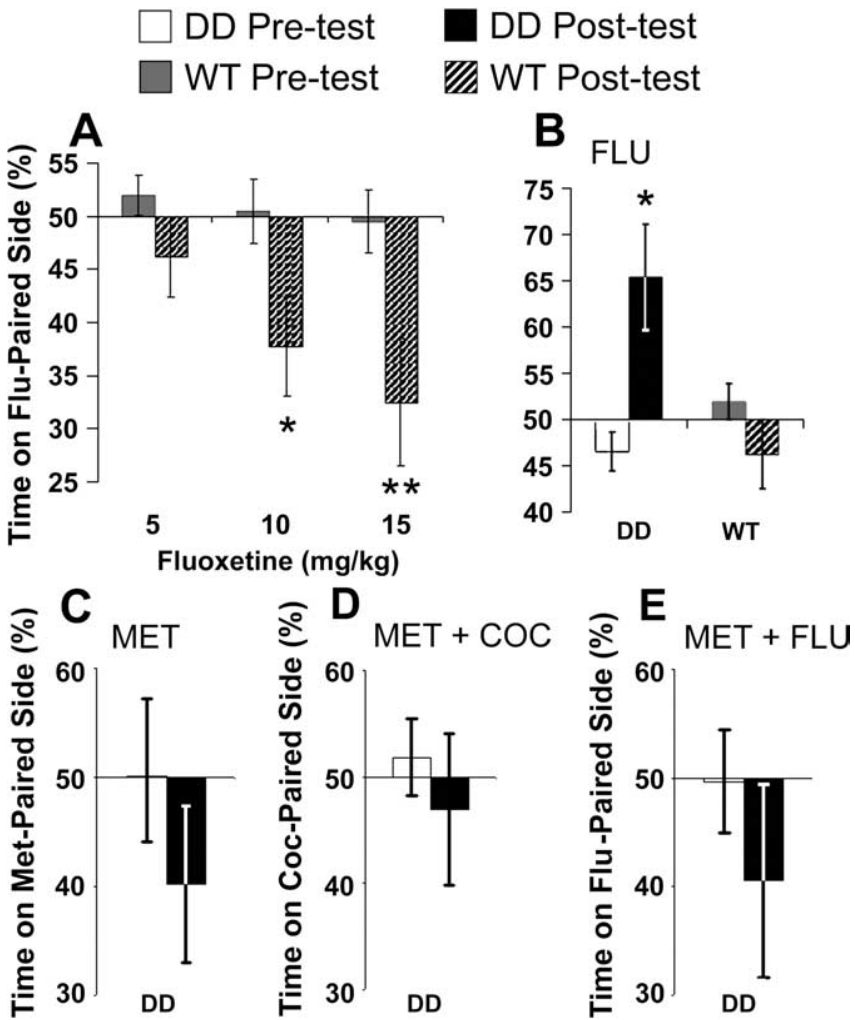

Figure 2. Serotonin mediates CPP in DD mice. $\boldsymbol{A}$, Dose-response for fluoxetine in control mice ( $n=9-12$ mice/dose; control, $n=20$ ); fluoxetine produced a conditioned place aversion at higher doses. $\boldsymbol{B}$, Fluoxetine (FLU; $5 \mathrm{mg} / \mathrm{kg}$ ) produced a CPP in DD but not control mice (DD $n=10$; controls, $n=20$ ). Note that control data from experiments $\boldsymbol{A}$ and $\boldsymbol{B}$ were combined. $\boldsymbol{C}$, The 5- $\mathrm{HT}_{1}$-receptor antagonist methiothepin (MET; $30 \mu \mathrm{g} / \mathrm{kg}$ ) did not induce a significant preference or aversion in DD mice $(n=9)$. $\boldsymbol{D}, \boldsymbol{E}$, Pretreatment with methiothepin blocked the formation of CPP for cocaine (COC; $10 \mathrm{mg} / \mathrm{kg}, n=8)$ and fluoxetine $(5 \mathrm{mg} / \mathrm{kg}, n=9)$ by DD mice, respectively. All data are presented as means \pm SEM of the percentage of time spent in the drug-paired during the pretesting and posttesting sessions; two-tailed paired $t$ test comparing time spent on drug-paired side before and after conditioning within genotypes and doses, ${ }^{*} p<0.05 ;{ }^{* *} p<0.01$. WT, Wild type.

resulted in cocaine-induced CPA in control mice. Because we observed that SERT blockade was sufficient to mediate CPP in DD mice, we also tested the effect of quinpirole on fluoxetinemediated CPP. Quinpirole pretreatment also blocked fluoxetine CPP in DD mice (Fig. 3C). These experiments suggest that dopamine neuron activity may be critical for cocaine- and fluoxetinemediated CPP, even when dopamine is not.

\section{Discussion}

We have shown that DD mice are capable of forming a CPP for cocaine, although within a narrowed dose range. We demonstrate that this cocaine $\mathrm{CPP}$ is independent of any remaining residual dopamine and is unaffected by a $\mathrm{D}_{1}$-receptor antagonist that blocks CPP in control mice. Our finding that fluoxetine can also produce CPP in DD mice, but not controls, suggests that increased serotonin signaling mediates cocaine CPP by DD mice. Finally, inhibition of dopamine neuron activity with a low dose of the $\mathrm{D}_{2}$-receptor agonist, quinpirole, is sufficient to block both cocaine and fluoxetine CPP by DD mice. We suggest that cocaine activates dopamine neurons through increased serotonin in DD mice and that dopamine neurons release an alternative neuromodulator that is critical for CPP.

The observation that cocaine elicits CPP in the absence of dopamine is curious in light of the ability of $D_{1}$-receptor antag- 
$\square$ DD Pre-test

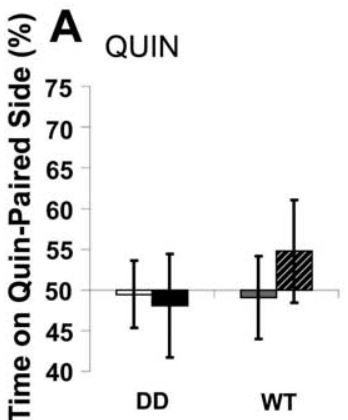

DD Post-test

$\square$ WT Pre-test

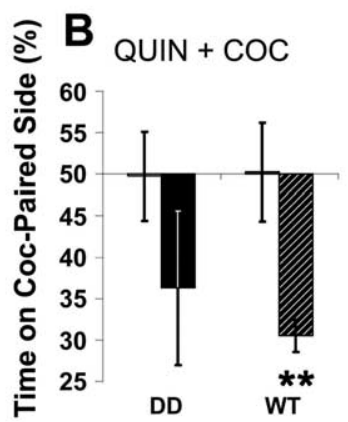

$\mathbb{Z}$ WT Post-test

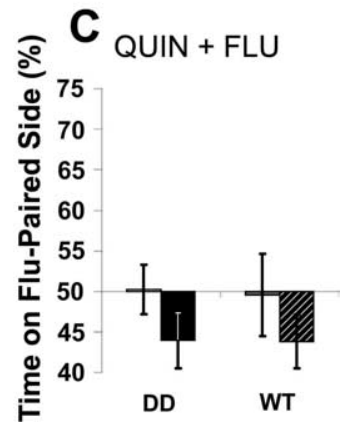

Figure 3. Quinpirole pretreatment blocks CPP. $A$, The $D_{2}$-receptor agonist quinpirole (QUIN; $50 \mu \mathrm{g} / \mathrm{kg}$ ) did not induce CPP or aversion in control mice (DD, $n=8$; controls, $n=7)$. $B$, Quinpirole $(50 \mu \mathrm{g} / \mathrm{kg})$ pretreatment blocked (or reversed) CPP for cocaine (COC; $10 \mathrm{mg} / \mathrm{kg}$ ) in both genotypes (DD, $n=7$; controls, $n=7$ ). C, Quinpirole (50 $\mu \mathrm{g} / \mathrm{kg}$ ) pretreatment blocked fluoxetine (FLU) CPP by DD mice (DD, $n=14$; for controls, $n=12$ ). All data are presented as means \pm SEM of the percentage of time spent in the drug-paired during the pretesting and posttesting sessions; two-tailed paired $t$ test comparing time spent on drug-paired side before and after conditioning within genotypes and doses, ${ }^{* *} p<0.01$. WT, Wild type.

onists to attenuate cocaine CPP in normal animals (Fig. 1C). However, DD mice only showed cocaine preference at intermediate doses of cocaine $(7.5$ and $10 \mathrm{mg} / \mathrm{kg})$. One potential explanation for this result is that cocaine reward is comprised of both dopamine-dependent and dopamine-independent components. The lack of CPP at low doses of cocaine may then indicate that the dopamine-independent pathway is not yet sufficiently engaged. The lack of CPP for high doses of cocaine likely reflects a predominance of the aversive effects of cocaine, which presumably occur at lower doses in the absence of dopamine. Thus, after acute cocaine treatment, dopamine release may augment the action of some other neurotransmitter and thereby broaden responsiveness to the hedonic impact or strengthen the associative learning processes that are required for CPP.

\section{SERT blockade mediates CPP by DD mice}

Because fluoxetine induced CPP in DD mice, the mechanism by which cocaine produces reward in the absence of dopamine is likely through increased serotonin signaling, despite the fact that acute SERT blockade can be aversive in normal animals (Fig. $2 \mathrm{~A}$ ). This conclusion is also supported by our observation that blockade of $5-\mathrm{HT}_{1}$ receptors disrupts the formation of CPP for both cocaine and fluoxetine. Although $5-\mathrm{HT}_{1}$ receptors are widespread throughout the brain, others have provided evidence that mesolimbic dopamine neurons serve as a locus at which cocaineinduced increases in 5- $\mathrm{HT}_{1}$ signaling activate dopamine neurons (Johnson et al., 1992; Cameron and Williams, 1994) and contribute to cocaine reward (Neumaier et al., 2002; David et al., 2004). However, in the absence of dopamine, how does SERT blockade mediate CPP? There is an interesting parallel with DAT-KO mice, which also retained cocaine CPP (Rocha et al., 1998a; Sora et al., 1998) and acquired CPP for serotonin-reuptake blockers (Hall et al., 2002; Mateo et al., 2004). In DAT-KO mice, cocaine still increased dopamine levels in the ventral (but not dorsal) striatum (Carboni et al., 2001; Mateo et al., 2004), and this increase has been offered as an explanation for their retention of cocaine CPP. Because DAT/SERT double-KO mice lack cocaine CPP (Sora et al., 2001), and because fluoxetine infusion directly into the ventral tegmental area (VTA) also increased extracellular dopamine in the NAc (Mateo et al., 2004), Mateo et al. (2004) suggested that cocaine-induced increases in serotonin signaling in the VTA activated dopamine neurons in DAT-KO mice. The chronically elevated levels of dopamine in the DAT-KO mice may have promoted a "switch" such that the net effect of increased serotonin signaling on to VTA dopamine neurons becomes excitatory. Although it may seem paradoxical, a similar mechanism could occur in DD mice, because DD mice are hyperdopaminergic for a few hours each day. Each daily injection of L-dopa elicits robust behavioral and molecular responses. For example, there is a dramatic induction of c-fos in the striatum (and elsewhere) that is comparable with that observed when control mice are given cocaine or amphetamine (Kim et al., 2000). These spikes of dopamine signaling may promote adaptations in the serotonin system similar to those in DAT-KO mice.

Mice bearing a mutant DAT that has essentially normal dopamine uptake activity, but does not bind cocaine, were shown to lack cocaine CPP (Chen et al., 2006). That result supports the conclusion that cocaine CPP observed in DAT-KO mice is a compensatory response to chronically elevated dopamine tone. However, the mice with mutated DAT were only tested for CPP at cocaine doses of 5 and $20 \mathrm{mg} / \mathrm{kg}$ (Chen et al., 2006), doses that failed to produce CPP in our DD mice and also failed to produce CPP by inbred DAT-KO mice (Medvedev et al., 2005), whereas intermediate doses were effective in both models.

Are dopamine neurons required for cocaine CPP by DD mice? We suggest that activity of dopamine neurons may still be important for cocaine CPP by DD mice even if they do not release dopamine, because quinpirole blocked both cocaine- and fluoxetine-mediated CPP. The firing rate of dopamine neurons of DD mice (measured in awake behaving mice) was inhibited by low doses of the $\mathrm{D}_{2}$-receptor agonist, quinpirole (Robinson et al., 2004). Quinpirole also blocked cocaine CPP in control mice, as might be expected as a result of activation of $\mathrm{D}_{2}$ autoreceptors on dopamine neurons and/or feedback via the indirect pathway. However, in addition to inhibiting dopamine neurons, quinpirole could directly affect acquisition or expression of CPP through activation of postsynaptic receptors. However, we are encouraged by the observations that the low dose of quinpirole we used had neither rewarding nor aversive effects by itself, but blocked both cocaine- and fluoxetine-mediated CPP. Definitive evidence that dopamine neuron activity is required for cocaine $\mathrm{CPP}$ will require a method for selectively silencing dopamine neurons.

If dopamine neuron activity is required for cocaine CPP in the absence of dopamine release, this would provide strong evidence that these neurons release other neuromodulators with biologically significant effects. Neuropeptides such as cholecystokinin and neurotensin are released by dopamine neurons and are capable of modulating behavioral responses to drugs of abuse (Geisler et al., 2006; Mitchell et al., 2006). In addition, emerging evidence suggests that glutamate is coreleased from dopamine neurons (Chuhma et al., 2004; Lavin et al., 2005). Thus, we suggest that in DD mice there are compensatory changes that allow cocaine-induced increases in serotonin to activate dopamine neurons, causing release of a nondopamine transmitter. The subsequent activation of nondopamine postsynaptic receptors in the 
striatum or other brain regions may then be essential for cocaine $\mathrm{CPP}$ in DD mice.

\section{References}

Berridge KC (2007) The debate over dopamine's role in reward: the case for incentive salience. Psychopharmacology (Berl) 191:391-431.

Cameron DL, Williams JT (1994) Cocaine inhibits GABA release in the VTA through endogenous 5-HT. J Neurosci 14:6763-6767.

Carboni E, Spielewoy C, Vacca C, Nosten-Bertrand M, Giros B, Di Chiara G (2001) Cocaine and amphetamine increase extracellular dopamine in the nucleus accumbens of mice lacking the dopamine transporter gene. J Neurosci 21:RC 141:141-144.

Cervo L, Samanin R (1995) Effects of dopaminergic and glutamatergic receptor antagonists on the acquisition and expression of cocaine conditioning place preference. Brain Res 673:242-250.

Chen R, Tilley MR, Wei H, Zhou F, Zhou FM, Ching S, Quan N, Stephens RL, Hill ER, Nottoli T, Han DD, Gu HH (2006) Abolished cocaine reward in mice with a cocaine-insensitive dopamine transporter. Proc Natl Acad Sci USA 103:9333-9338.

Chuhma N, Zhang H, Masson J, Zhuang X, Sulzer D, Hen R, Rayport S (2004) Dopamine neurons mediate a fast excitatory signal via their glutamatergic synapses. J Neurosci 24:972-981.

David V, Segu L, Buhot MC, Ichaye M, Cazala P (2004) Rewarding effects elicited by cocaine microinjections into the ventral tegmental area of C57BL/6 mice: involvement of dopamine D1 and serotonin1B receptors. Psychopharmacology (Berl) 174:367-375.

Geisler S, Berod A, Zahm DS, Rostene W (2006) Brain neurotensin, psychostimulants, and stress-emphasis on neuroanatomical substrates. Peptides 27:2364-2384.

Hall FS, Li XF, Sora I, Xu F, Caron M, Lesch KP, Murphy DL, Uhl GR (2002) Cocaine mechanisms: enhanced cocaine, fluoxetine and nisoxetine place preferences following monoamine transporter deletions. Neuroscience 115:153-161.

Heusner CL, Hnasko TS, Szczypka MS, Liu Y, During MJ, Palmiter RD (2003) Viral restoration of dopamine to the nucleus accumbens is sufficient to induce a locomotor response to amphetamine. Brain Res 980:266-274

Hnasko TS, Sotak BN, Palmiter RD (2005) Morphine reward in dopaminedeficient mice. Nature 438:854-857.

Johnson SW, Mercuri NB, North RA (1992) 5-hydroxytryptamine ${ }_{1 B}$ receptors block the $\mathrm{GABA}_{\mathrm{B}}$ synaptic potential in rat dopamine neurons. J Neurosci 12:2000-2006.

Kim DS, Szczypka MS, Palmiter RD (2000) Dopamine-deficient mice are hypersensitive to dopamine receptor agonists. J Neurosci 20:4405-4413.

Lavin A, Nogueira L, Lapish CC, Wightman RM, Phillips PE, Seamans JK (2005) Mesocortical dopamine neurons operate in distinct temporal domains using multimodal signaling. J Neurosci 25:5013-5023.

Mateo Y, Budygin EA, John CE, Jones SR (2004) Role of serotonin in cocaine effects in mice with reduced dopamine transporter function. Proc Natl Acad Sci USA 101:372-377.

Medvedev IO, Gainetdinov RR, Sotnikova TD, Bohn LM, Caron MG, Dykstra LA (2005) Characterization of conditioned place preference to cocaine in congenic dopamine transporter knockout female mice. Psychopharmacology (Berl) 180:408-413.

Mitchell JM, Bergren LJ, Chen KS, Fields HL (2006) Cholecystokinin is necessary for the expression of morphine conditioned place preference. Pharmacol Biochem Behav 85:787-795.
Neumaier JF, Vincow ES, Arvanitogiannis A, Wise RA, Carlezon Jr WA (2002) Elevated expression of 5- $\mathrm{HT}_{1 \mathrm{~B}}$ receptors in nucleus accumbens efferents sensitizes animals to cocaine. J Neurosci 22:10856-10863.

Parsons LH, Weiss F, Koob GF (1998) Serotonin ${ }_{1 \mathrm{~B}}$ receptor stimulation enhances cocaine reinforcement. J Neurosci 18:10078-10089.

Pettit HO, Ettenberg A, Bloom FE, Koob GF (1984) Destruction of dopamine in the nucleus accumbens selectively attenuates cocaine but not heroin self-administration in rats. Psychopharmacology (Berl) 84:167-173.

Pierce RC, Kumaresan V (2006) The mesolimbic dopamine system: the final common pathway for the reinforcing effect of drugs of abuse? Neurosci Biobehav Rev 30:215-238.

Pruitt DL, Bolanos CA, McDougall SA (1995) Effects of dopamine D1 and D2 receptor antagonists on cocaine-induced place preference conditioning in preweanling rats. Eur J Pharmacol 283:125-131.

Ritz MC, Lamb RJ, Goldberg SR, Kuhar MJ (1987) Cocaine receptors on dopamine transporters are related to self-administration of cocaine. Science 237:1219-1223.

Robinson S, Smith DM, Mizumori SJ, Palmiter RD (2004) Firing properties of dopamine neurons in freely moving dopamine-deficient mice: effects of dopamine receptor activation and anesthesia. Proc Natl Acad Sci USA 101:13329-13334.

Rocha BA, Fumagalli F, Gainetdinov RR, Jones SR, Ator R, Giros B, Miller GW, Caron MG (1998a) Cocaine self-administration in dopaminetransporter knockout mice. Nat Neurosci 1:132-137.

Rocha BA, Scearce-Levie K, Lucas JJ, Hiroi N, Castanon N, Crabbe JC, Nestler EJ, Hen R (1998b) Increased vulnerability to cocaine in mice lacking the serotonin-1B receptor. Nature 393:175-178.

Rothman RB, Baumann MH (2003) Monoamine transporters and psychostimulant drugs. Eur J Pharmacol 479:23-40.

Rothman RB, Glowa JR (1995) A review of the effects of dopaminergic agents on humans, animals, and drug-seeking behavior, and its implications for medication development. Focus on GBR 12909. Mol Neurobiol 11:1-19.

Schultz W (2002) Getting formal with dopamine and reward. Neuron 36:241-263.

Sora I, Wichems C, Takahashi N, Li XF, Zeng Z, Revay R, Lesch KP, Murphy DL, Uhl GR (1998) Cocaine reward models: conditioned place preference can be established in dopamine- and in serotonin-transporter knockout mice. Proc Natl Acad Sci USA 95:7699-7704.

Sora I, Hall FS, Andrews AM, Itokawa M, Li XF, Wei HB, Wichems C, Lesch KP, Murphy DL, Uhl GR (2001) Molecular mechanisms of cocaine reward: combined dopamine and serotonin transporter knockouts eliminate cocaine place preference. Proc Natl Acad Sci USA 98:5300-5305.

Spyraki C, Fibiger HC, Phillips AG (1982) Cocaine-induced place preference conditioning: lack of effects of neuroleptics and 6-hydroxydopamine lesions. Brain Res 253:195-203.

Szczypka MS, Rainey MA, Kim DS, Alaynick WA, Marck BT, Matsumoto AM, Palmiter RD (1999) Feeding behavior in dopamine-deficient mice. Proc Natl Acad Sci USA 96:12138-12143.

Wise RA (2004) Dopamine, learning and motivation. Nat Rev Neurosci 5:483-494.

Xu F, Gainetdinov RR, Wetsel WC, Jones SR, Bohn LM, Miller GW, Wang YM, Caron MG (2000) Mice lacking the norepinephrine transporter are supersensitive to psychostimulants. Nat Neurosci 3:465-471.

Zhou QY, Palmiter RD (1995) Dopamine-deficient mice are severely hypoactive, adipsic, and aphagic. Cell 83:1197-1209. 